\title{
Pelatihan "Sex? It Isn't Taboo Anymore" untuk Meningkatkan Pengetahuan dan Asertivitas Seksual Remaja
}

\author{
Ellyana Dwi Farisandy, Endang Retno Surjaningrum \\ Magister Profesi Psikologi Universitas Airlangga, Surabaya, Indonesia \\ e-mail: ellyanadwif@gmail.com
}

\begin{abstract}
This study aims to determine the effect of sexuality training to increasing the knowledge of sexuality and sexual assertiveness behavior in adolescents. This study used preexperimental design, with one group pretest posttest design, where only one group will be given treatment. The research sample was selected using total sampling method. The subjects of this study were 12 members of Posyandu Puskesmas X aged 11-20 years. Sexuality knowledge was measured using an instrument prepared by researchers, while Sexual Assertiveness Scale (SAS) was used to measure sexual assertiveness. The intervention consists of eight sessions of sexuality training for two days. Data was analyzed using wilcoxon signed rank test. The results show that sexuality training is effective to increasing knowledge and sexual assertiveness, and it is expected to be able to prevent teenagers from engaging in premarital sexual behavior.
\end{abstract}

Keywords: adolescence, sexuality training, premarital sex

\begin{abstract}
Abstrak
Penelitian ini bertujuan mengetahui pengaruh pelatihan seksualitas dalam meningkatkan pengetahuan dan asertivitas seksual pada remaja. Metode penelitian menggunakan praeksperimen, yakni one group pretest posttest design dimana hanya terdapat satu kelompok yang diberikan perlakuan. Sampel penelitian dipilih dengan menggunakan metode total sampling. Subjek penelitian adalah 12 anggota Pos Pelayanan Terpadu (Posyandu) remaja Puskesmas X yang berusia 11-20 tahun. Alat ukur pengetahuan seksualitas disusun oleh peneliti, sedangkan alat ukur asertivitas menggunakan Sexual Assertiveness Scale (SAS). Intervensi diberikan dalam delapan sesi pelatihan seksualitas yang terbagi menjadi dua hari. Analisa data menggunakan wilcoxon signed rank test. Hasil menunjukkan bahwa pelatihan seksualitas efektif dalam meningkatkan pengetahuan dan asertivitas seksual remaja, sehingga hal tersebut diharapkan dapat mencegah para remaja untuk melakukan perilaku seks pranikah.
\end{abstract}

Kata Kunci: remaja, pelatihan seksualitas, seks pranikah

\section{Pendahuluan}

Fenomena kasus seks pranikah pada remaja semakin meningkat setiap tahunnya, terlebih di Indonesia. Survei Demografi Kesehatan Indonesia dari dua periode yang berbeda (2002-2003 dan 2012) mengungkapkan bahwa seks pranikah di kalangan remaja Indonesia berusia 15-24 tahun meningkat dari 5\% menjadi $8 \%$ untuk pria dan konstan $1 \%$ untuk wanita (BPS dalam Berliana dkk., 2018).

Selain itu, Survei Kesehatan Reproduksi Remaja Indonesia (SKRRI) dari tiga periode yang berbeda $(2003,2007$, dan 2012) menjelaskan bahwa seks pranikah di kalangan remaja berusia 15-24 tahun meningkat dari 5\% (2002) menjadi 6\% (2003) dan melonjak naik menjadi $19.1 \%$ (2012) untuk remaja pria. Pada remaja wanita, angka tersebut relatif konstan yakni $1 \%$ pada tiga periode $(2002$, 2003, dan 2012) (Australian National University dalam Utomo \& Utomo, 2013).

Seks pranikah merupakan salah satu aktivitas seksual dimana adanya kontak langsung antara penis dan vagina hingga terjadi penetrasi (Fajri, 2016). Aktivitas tersebut terjadi oleh individu dengan 
individu lainnya tanpa adanya ikatan perkawinan (Rahardjo dkk., 2017). Dampak negatif yang ditimbulkan seks pranikah juga sangat banyak, baik dari segi fisiologis, psikologis, maupun sosial.

Berdasar segi fisiologis, para remaja dapat mengalami kehamilan yang tidak diinginkan, praktik aborsi yang tidak aman, hingga meningkatkan risiko penyakit menular seksual (PMS). Berdasar segi psikologis, para remaja akan merasa menyesal, rendah diri, depresi, marah, cemas, merasa berdosa, merasa bersalah, dan perasaan negatif lainnya karena hal tersebut tidak sesuai dengan nilai yang mereka yakini dan atau ketika mereka melakukan seks pranikah yang dipaksakan (Abdissa dkk., 2017; Abdullahi \& Umar, 2013; Asamoah \& Agardh, 2018; Elkington dkk., 2012; Ghaffari dkk., 2016; Sarwono, 2003; Olubunmi, 2011; Scott dkk., 2011).

Berdasar segi sosial, para remaja kemungkinan akan kehilangan dukungan dari keluarga dan lingkungan terdekat, prestasi akademik yang menurun, putus sekolah, adanya pernikahan dini serta mendapatkan tekanan maupun cemoohan dari lingkungan sekitarnya (Abdissa dkk., 2017; Abdullahi \& Umar, 2013; Asamoah \& Agardh, 2018; Elkington dkk., 2012; Ghaffari dkk., 2016; Sarwono, 2003; Olubunmi, 2011; Scott dkk., 2011).

Terdapat beberapa faktor yang membuat para remaja melakukan seks pranikah. Asamoah dan Argardh (2018) melakukan studi cross-sectional pada individu dengan rentang usia 18-29 tahun di Sweden. Penelitian tersebut mengungkapkan bahwa faktor individu seperti pencari sensasi dan impulsivitas serta faktor keluarga seperti keluarga yang memiliki status ekonomi sosial (SES) rendah, tinggal dalam keluarga yang tidak stabil, dan atau dibesarkan oleh orang tua yang berpendidikan rendah dapat meningkatkan risiko individu untuk melakukan perilaku seks pranikah.

Penelitian dari Elkington dkk. (2012) di Kota New York menjelaskan bahwa remaja yang tinggal di lingkungan perkotaan yang miskin serta adanya pengaruh teman sebaya yang negatif juga merupakan faktor risiko remaja melakukan seks pranikah. Selain itu, remaja yang memiliki konsep diri yang buruk dimana remaja merasa terasing dan atau kecewa dengan keluarga mereka lebih cenderung untuk melakukan perilaku seks pranikah.

Scott dkk. (2011) juga melakukan penelitian dengan subjek 5.798 remaja yang penah melakukan seks setidaknya dengan satu pasangan di Amerika Serikat. Hasil menunjukkan bahwa etnis minoritas seperti etnis Hispanik umumnya berhubungan positif dengan perilaku seksual berisiko. Selain itu, prestasi akademik, aspirasi terhadap pendidikan, serta penghindaran terhadap obat-obatan dan atau alkohol umumnya berhubungan negatif dengan perilaku seksual berisiko. Pendidikan ibu yang lebih tinggi, kedekatan orang tua-anak yang lebih stabil, serta struktur keluarga yang utuh merupakan faktor protektif remaja terhadap perilaku seksual berisiko.

Berdasarkan beberapa faktor tersebut, Warner (2018) menyimpulkan faktor risiko dengan menggunakan model ekologi sosial pada perilaku seks pranikah yang dilakukan oleh remaja, yakni: (a) faktor individu, misalnya pubertas, gangguan psikologis seperti depresi serta kenakalan remaja; (b) keluarga, seperti hubungan antara orang tua dan anak; (c) teman sebaya, misalnya teman yang telah melakukan perilaku seks pranikah; (d) lingkungan, misalnya tinggal di lingkungan dengan SES rendah membuat remaja melakukan hubungan seks lebih awal dan jarang menggunakan kontrasepsi dibandingkan remaja yang tinggal di keluarga dengan SES lebih baik; (e) struktur peluang, misalnya akses terhadap pekerjaan dan pendidikan; (f) sumber daya masyarakat dan kelembagaan, misalnya layanan KB serta kegiatan rekreasi; (g) disorganisasi sosial, seperti kejahatan; serta (h) adanya komposisi ras dan atau etnis.

Selain disebabkan faktor tersebut di atas, perilaku seks pranikah juga dapat 
disebabkan rendahnya pengetahuan remaja mengenai isu seksualitas (Sarwono, 2003; Kartono, 2013; Fajri, 2016; Rahardjo dkk., 2017). Kurangnya pemahaman para remaja mengenai isu seksualitas yang benar dari keluarga serta makin cepatnya perkembangan teknologi membuat para remaja dengan mudah mendapatkan informasi yang belum tentu benar dari internet, teman, ataupun dengan melihat video porno (Odek, 2006). Adanya permasalahan tersebut sesuai dengan Hurlock (dalam Kusumastuti, 2017) yang mengungkapkan bahwa hanya sedikit remaja yang mendapatkan informasi seksualitas dari orang tua.

Terdapat beberapa alasan orang tua tidak memberikan pendidikan seksualitas pada anak, antara lain: keterbatasan pengetahuan orang tua mengenai reproduksi remaja, rasa malu yang membuat orang tua menolak untuk menyampaikan informasi mengenai kesehatan reproduksi, serta persepsi orang tua mengenai norma konservatif terkait pendidikan seksualitas yang akhirnya membuat pembicaraan mengenai isu seksualitas menjadi hal yang tabu. Orang tua menganggap bahwa pendidikan seksualitas terlalu vulgar dan tidak pantas untuk diberikan kepada anak. Orang tua juga khawatir jika pendidikan seks akan memicu anak untuk mencari tahu hal-hal yang berkaitan dengan seksualitas dan akhirnya meniru perilaku seksual tersebut (Meilani dkk., 2014; Amaliyah \& Nuqul, 2017).

Odek (2006) mengungkapkan bahwa pendidikan seksualitas merupakan salah satu cara untuk mengurangi dan atau mencegah adanya perilaku seks pranikah, kehamilan yang tidak diinginkan, aborsi, pemerkosaan, penularan penyakit menular seksual serta dapat meningkatkan kualitas hubungan. Lebih lanjut, Meilani dkk. (2014) menjelaskan bahwa pendidikan seksualitas dapat mengurangi informasi mengenai seksualitas yang keliru, meningkatkan pengetahuan seksualitas yang tepat, menguatkan nilai dan sikap yang positif, serta meningkatkan keterampilan individu dalam mengambil keputusan. Remaja juga dapat menghindarkan dan atau menunda hubungan seksual, menurunkan frekuensi perilaku seksual yang tidak aman, mengurangi jumlah pasangan dalam melakukan aktivitas seksual, serta meningkatkan proteksi pada kehamilan yang tidak diinginkan dan infeksi menular seksual.

Teknik intervensi yang dipilih merupakan metode psikoedukasi dengan menggunakan pelatihan. Pemberian pelatihan ini menggunakan metode yang bervariasi yakni ceramah, diskusi, bermain peran, serta games sehingga pelatihan ini dapat lebih mudah diterima oleh para remaja dan dapat meminimalisir kebosanan yang dirasakan. Tujuan dilakukannya pelatihan ini untuk memberikan informasi berkaitan dengan seksualitas dan memberikan keterampilan sehingga para remaja dapat bertindak asertif untuk menolak berhubungan seks ketika mereka belum siap mengenai konsekuensi yang akan mereka terima.

Dalam melakukan penelitian ini, peneliti memilih sebuah layanan kesehatan berbasis komunitas yaitu puskesmas. Peneliti melakukan kolaborasi dengan puskesmas dan memilih Posyandu remaja untuk melaksanakan pelatihan tersebut. Berdasarkan data awal dengan metode wawancara ditemukan bahwa teman sebaya dari para remaja tersebut menunjukkan perilaku berpacaran dengan cara berpegangan tangan, memeluk, mencium pipi, serta mengajak pasangannya pergi ke taman. Akan tetapi, terdapat pula yang menunjukkan perilaku berpacaran dengan melakukan hubungan seks pranikah.

Tujuan dari pelatihan ini adalah sebagai langkah preventif untuk meningkatkan pemahaman mengenai isu seksualitas dan keterampilan asertivitas seksual para peserta komunitas Posyandu remaja. Hal ini diharapkan dapat 
mengurangi risiko remaja terjerumus dalam perilaku seks pranikah. Terdapat dua hipotesis dalam penelitian ini, yakni: (a) pelatihan seksualitas efektif dalam meningkatkan pengetahuan seksualitas remaja, serta (b) pelatihan seksualitas efektif dalam meningkatkan asertivitas seksual remaja.

\section{Metode Penelitian}

\section{Rancangan Penelitian}

Penelitian ini menggunakan desain penelitian pre-experimental, yakni one group pretest-posttest design. Metode ini hanya menggunakan satu kelompok dimana terdapat pemberian kuesioner sebelum dan setelah adanya intervensi. Alasan peneliti menggunakan metode ini disebabkan keterbatasan peneliti serta keterbatasan waktu untuk membagi sampel menjadi dua kelompok yakni kelompok eksperimen dan kelompok kontrol.

\section{Partisipan Penelitan}

Penelitian ini menggunakan teknik pengambilan sampel whole sampling. Kriteria inklusi subjek penelitian ini yakni: 1) Remaja yang tinggal di wilayah layanan Puskesmas X; 2) Merupakan anggota Posyandu Remaja; 3) Berjenis kelamin laki-laki; 4) Belum pernah melakukan seks pranikah; 5) Memiliki rentang usia 11-20 tahun; serta 6) Bersedia mengikuti seluruh rangkaian pelatihan selama dua hari.

\section{Alat Pengumpulan Data}

Penelitian ini menggunakan dua alat ukur, yakni kuesioner pengetahuan dan Sexual Assertiveness Scale (SAS). Kuesioner pengetahuan disusun oleh peneliti sendiri sesuai dengan materi yang diberikan kepada partisipan. Kuesioner tersebut terdiri dari 5 item. Skor yang didapatkan berkisar antara 0-100. Di samping itu, SAS digunakan untuk mengetahui asertivitas seksual individu terdiri dari 18 item sebagaimana disajikan pada tabel 1. Morokoff dkk. (1997) awalnya membuat skala asertivitas seksual yang hanya ditujukan kepada wanita. Sierra dkk. (2012) kemudian melakukan penelitian dengan mengevaluasi kesetaraan faktorial dan metrik berdasarkan jenis kelamin. Hasil penelitiannya adalah tidak ada bias yang signifikan dalam skala ketika membandingkan antara jenis kelamin sehingga alat ukur SAS dapat digunakan baik kepada pria maupun wanita. VallejoMedina dan Sierra (2015) juga telah melakukan penelitian asertivitas seksual yang ditujukan kepada laki-laki.

Terdapat tiga dimensi dari SAS antara lain: (a) Inisiatif (initiation), yakni kemampuan seseorang untuk memulai dan mengambil tindakan terlebih dahulu dalam aktivitas seksual yang diinginkan; (b) penolakan (refusal), yakni kemampuan seseorang untuk menolak aktivitas seksual yang tidak diinginkan; serta (c) pencegahan kehamilan dan infeksi menular seksual (IMS) (STD-Pregnancy Prevention), yakni kemampuan seseorang untuk melakukan inisiatif dan penolakan dalam aktivitas seksual yang dikaitkan dengan topik khusus, yakni penggunaan pengaman untuk mencegah kehamilan dan penyakit menular seksual (Lubis \& Oriza, 2000; Morokoff dkk., 1997). Dalam penelitian ini, peneliti hanya berfokus pada satu dimensi, yakni penolakan (refusal). Alat ukur ini menggunakan skala Likert dengan rentang 1-4 yakni (1) sangat tidak sesuai, (2) tidak sesuai, (3) sesuai, dan (4) sangat sesuai.

\section{Prosedur Penelitian}

Pelatihan seksualitas ini berjudul "Sex? It Isn't Taboo Anymore". Pelatihan ini dilaksanakan selama dua hari dan terdiri dari delapan sesi. Terdapat beberapa metode dalam pelatihan ini, yakni diskusi, ceramah, bermain peran, menonton video, serta games. Asesmen dilakukan selama satu kali, yakni untuk menanyakan mengenai identitas dan latar belakang partisipan pelatihan.

Sebelum melakukan pelatihan seksualitas, peneliti melakukan asesmen mengacu pada teori ekologi Bronfenbenner 
Pelatihan "Sex? It Isn't Taboo Anymore" untuk Meningkatkan Pengetahuan dan Asertivitas Seksual Remaja (Ellyana Dwi Farisandy, Endang Retno Surjaningrum)

(Sunsern \& Lawang, 2019). Berkaitan dengan mikrosistem, peneliti melakukan wawancara kepada kader Posyandu remaja dan orang tua dari kader Posyandu remaja. Hal ini dilakukan untuk mengetahui permasalahan berdasarkan sudut pandang kader maupun orang tua. Terkait mesosistem, peneliti melakukan wawancara kepada Ketua RT/RW. Hal ini dilakukan untuk mengetahui aturan yang telah diterapkan untuk mengurangi angka seks pranikah pada remaja di sekitar kawasan tersebut.

Terkait makrosistem, peneliti melakukan wawancara kepada pihak-pihak puskesmas, seperti kepala Puskesmas, konselor, staf program kesehatan, dokter, bidan kesehatan ibu dan anak (KIA), serta penanggung jawab calon pengantin di Puskesmas X. Hal ini dilakukan dengan tujuan untuk mengetahui data mengenai remaja yang hamil di luar pernikahan serta cara yang telah dilakukan oleh pihak puskesmas untuk mencegah adanya seks pranikah pada remaja.

Setelah menyelesaikan proses asesmen, peneliti lalu membuat inform consent, modul pelatihan, workbook, slide presentation, kuesioner pengetahuan serta menemukan alat ukur yang sesuai. Modul pelatihan dibuat dengan melakukan adaptasi pada modul Sexual and Reproductive Health Training Manual for Young People yang disusun oleh German Foundation for World Population (2006) serta Modul Psikoedukasi Kesehatan Reproduksi dari Kusumastuti (2010).

Tabel 1

Blueprint Sexual Assertiveness Scale (SAS)

\begin{tabular}{lccc}
\hline & \multicolumn{2}{c}{ Nomor Item } & \\
\cline { 2 - 3 } \multicolumn{1}{c}{ Dimensi } & Favorable & Unfavorable & Jumlah \\
\hline Initiation & $1,2,5$ & $3,4,6$ & 6 \\
Refusal & $9,11,12$ & $7,8,10$ & 6 \\
STD - & & & \\
$\begin{array}{l}\text { Pregnancy } \\
\text { prevention }\end{array}$ & $15,17,18$ & $13,14,16$ & 6 \\
\hline
\end{tabular}

Tabel 2

Blueprint Materi Pelatihan

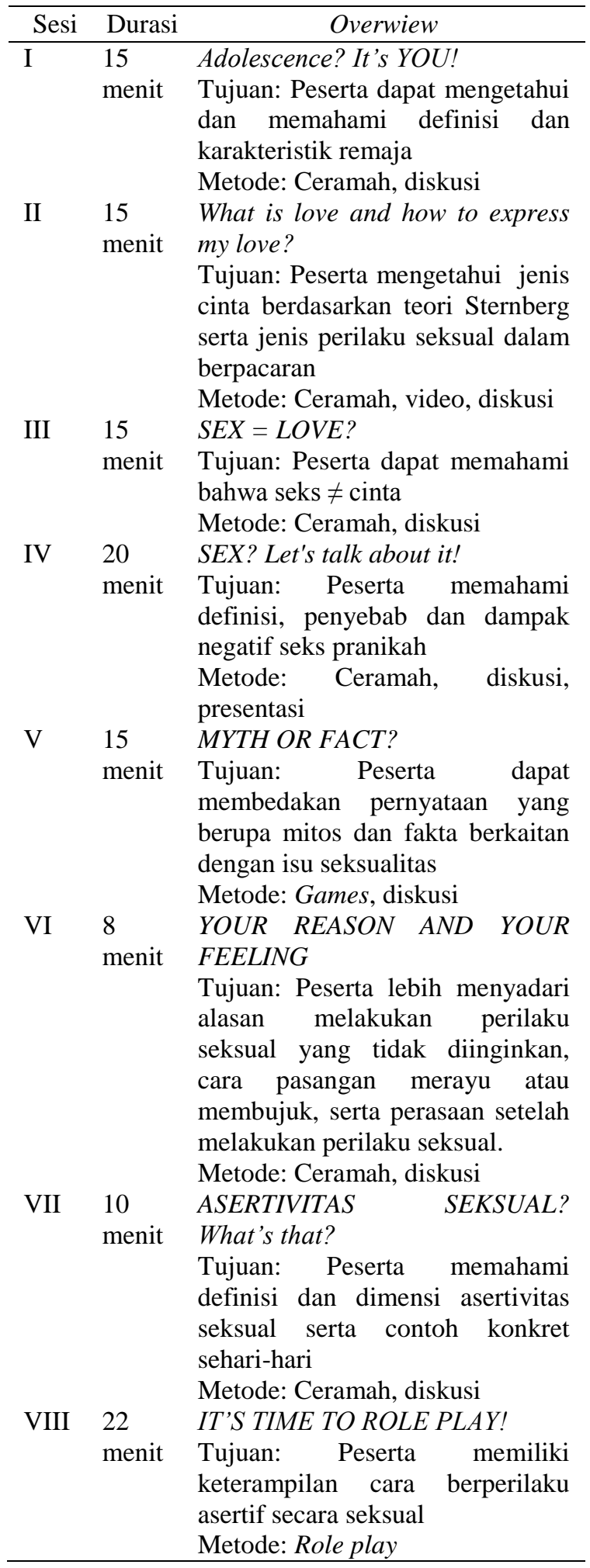

Setelah itu, peneliti juga mengatur jadwal dengan partisipan pelatihan serta bekerja sama dengan pihak Puskesmas berkaitan dengan peminjaman alat dan 
ruangan. Setelah semuanya terpenuhi, barulah peneliti melakukan pelatihan seksualitas tersebut. Alat ukur diberikan pada saat sebelum dan setelah pelatihan berlangsung. Peneliti juga memberikan lembar evaluasi di akhir kegiatan sehingga peserta dapat mengevaluasi kegiatan tersebut secara keseluruhan, baik dari segi penguasaan dan keterampilan fasilitator, materi, handout, maupun sarana prasarana. Tabel 2 menyajikan rincian sesi pelatihan seksualitas yang telah peneliti susun.

\section{Teknik Analisis Data}

Pengujian hipotesis menggunakan uji beda sampel berpasangan yakni wilcoxon signed rank test dan effect size. Perhitungan effect size dilakukan dengan menggunakan G-Power.

\section{Hasil Penelitian dan Pembahasan}

Berdasarkan tabel 3 dapat dijelaskan bahwa terdapat peningkatan skor pengetahuan keseluruhan subjek pada saat sebelum pelatihan (pretest) dan saat setelah pelatihan (posttest). Sedangkan pada tabel 4 dapat terlihat bahwa 12 partisipan mengalami kenaikan skor perilaku asertivitas seksual dan 1 partisipan mengalami skor yang tetap pada saat sebelum pelatihan (pretest) dan saat setelah pelatihan (posttest).

Uji normalitas bertujuan untuk mengetahui apakah data berdistribusi secara normal atau tidak yang dapat dilihat dari nilai Skewness dan Kurtosis. Sebuah data dikatakan normal jika nilai Skewness berkisar antara -1 hingga 1 serta nilai Kurtosis berkisar antara -2 hingga 2 . Berdasarkan tabel 5 dapat dijelaskan bahwa keempat skor berdistribusi normal.
Tabel 3

Distribusi Frekuensi Berdasarkan Skor

Pengetahuan

\begin{tabular}{|c|c|c|c|c|c|}
\hline No & Nama & $\begin{array}{c}\text { Skor } \\
\text { pretest }\end{array}$ & $\begin{array}{c}\text { Skor } \\
\text { posttest }\end{array}$ & $\begin{array}{l}\text { Gain } \\
\text { score }\end{array}$ & Ket \\
\hline 1 & $\overline{\mathrm{DM}}$ & 36 & 74 & 38 & Naik \\
\hline 2 & $\mathrm{ZN}$ & 36 & 65 & 29 & Naik \\
\hline 3 & IA & 18 & 83 & 65 & Naik \\
\hline 4 & $\mathrm{KO}$ & 8 & 81 & 73 & Naik \\
\hline 5 & DP & 17 & 77 & 60 & Naik \\
\hline 6 & SI & 14 & 90 & 76 & Naik \\
\hline 7 & $\mathrm{MF}$ & 22 & 90 & 68 & Naik \\
\hline 8 & MA & 18 & 65 & 47 & Naik \\
\hline 9 & AK & 26 & 86 & 60 & Naik \\
\hline 10 & $\mathrm{RP}$ & 20 & 81 & 61 & Naik \\
\hline 11 & FA & 55 & 91 & 36 & Naik \\
\hline 12 & MR & 58 & 84 & 26 & Naik \\
\hline
\end{tabular}

Berdasarkan tabel 6 dapat dijelaskan bahwa rata-rata skor pengetahuan pada saat posttest $(\mathrm{M}=80.58)$ lebih tinggi dibandingkan rata-rata skor partisipan pada saat pretest $(\mathrm{M}=27.33)$. Selain itu, hasil uji hipotesis wilcoxon signed rank test menunjukkan bahwa Asymp sig. (2-tailed) adalah .002 (< $.05)$ dengan perbedaan rerata -53.25 . Hal ini mengindikasikan bahwa terdapat perbedaan yang signifikan pengetahuan partisipan sebelum diberikannya pelatihan dan setelah diberikannya pelatihan. Jadi, dapat disimpulkan bahwa pelatihan tersebut efektif dalam meningkatkan pengetahuan partisipan.

Berdasarkan tabel 7 dapat dijelaskan bahwa rata-rata skor asertivitas seksual pada saat posttest $(\mathrm{M}=49.33)$ lebih tinggi dibandingkan pretest $(\mathrm{M}=46.33)$. Selain itu, hasil uji hipotesis wilcoxon signed rank test menunjukkan bahwa Asymp sig. (2-tailed) yakni .003 $(p<.05)$ dengan perbedaan mean -3.000 sehingga dapat dijelaskan bahwa terdapat perbedaan yang signifikan pada skor perilaku asertivitas seksual partisipan sebelum diberikan pelatihan dan setelah diberikannya pelatihan. Jadi, dapat disimpulkan bahwa pelatihan seksualitas efektif dalam meningkatkan kemampuan asertivitas seksual partisipan. 
Pelatihan "Sex? It Isn't Taboo Anymore" untuk Meningkatkan Pengetahuan dan Asertivitas Seksual Remaja (Ellyana Dwi Farisandy, Endang Retno Surjaningrum)

Tabel 4

Distribusi Frekuensi Berdasarkan Asertivitas Seksual

\begin{tabular}{cccccc}
\hline No & Nama & $\begin{array}{c}\text { Skor } \\
\text { pretest }\end{array}$ & $\begin{array}{c}\text { Skor } \\
\text { posttest }\end{array}$ & $\begin{array}{c}\text { Gain } \\
\text { score }\end{array}$ & Ket \\
\hline 1 & DM & 44 & 46 & 2 & Naik \\
2 & ZN & 45 & 50 & 5 & Naik \\
3 & IA & 44 & 53 & 9 & Naik \\
4 & KO & 45 & 47 & 2 & Naik \\
5 & DP & 45 & 46 & 1 & Naik \\
6 & SI & 45 & 48 & 3 & Naik \\
7 & MF & 44 & 48 & 4 & Naik \\
8 & MA & 45 & 45 & 0 & Tetap \\
9 & AK & 52 & 55 & 3 & Naik \\
10 & RP & 52 & 53 & 1 & Naik \\
11 & FA & 45 & 47 & 2 & Naik \\
12 & MR & 51 & 54 & 3 & Naik \\
\hline
\end{tabular}

Tabel 5

Hasil Uji Normalitas

\begin{tabular}{lrrc}
\hline \multirow{2}{*}{ Variabel } & \multicolumn{2}{c}{ Uji Normalitas Data } & Sebaran \\
\cline { 2 - 3 } & Skweness & Kurtosis & data \\
\hline $\begin{array}{l}\text { Pretest } \\
\text { pengetahuan }\end{array}$ & 1.048 & .141 & Normal \\
$\begin{array}{l}\text { Posttest } \\
\text { pengetahuan }\end{array}$ & -.751 & -.334 & Normal \\
$\begin{array}{l}\text { Pretest } \\
\text { asertivitas } \\
\text { seksual }\end{array}$ & 1.274 & -.257 & Normal \\
$\begin{array}{l}\text { Posttest } \\
\text { asertivitas } \\
\text { seksual }\end{array}$ & .490 & -1.448 & Normal \\
\hline
\end{tabular}

Tabel 6

Distribusi Frekuensi Skor Pengetahuan

\begin{tabular}{ccccc}
\hline \multicolumn{2}{c}{ Mean } & \multicolumn{2}{c}{ SD } & $\begin{array}{c}\text { Asymp sig. (2 } \\
\text { tailed) }\end{array}$ \\
\cline { 1 - 3 } Pretest & Posttest & Pretest & Posttest & .002 \\
\hline 27.33 & 80.58 & 15.87 & 8.91 & .002 \\
\hline
\end{tabular}

Tabel 7

Distribusi Frekuensi Skor Asertivitas Seksual

\begin{tabular}{ccccc}
\hline \multicolumn{2}{c}{ Mean } & \multicolumn{2}{c}{ SD } & $\begin{array}{c}\text { Asymp sig. (2 } \\
\text { tailed) }\end{array}$ \\
\cline { 1 - 3 } Pretest & Posttest & Pretest & Posttest & \\
\hline 46.33 & 49.33 & 3.05 & 3.52 & .003 \\
\hline
\end{tabular}

Tabel 8

Distribusi Frekuensi Aspek Refusal

\begin{tabular}{ccccc}
\hline \multicolumn{2}{c}{ Mean } & \multicolumn{2}{c}{ SD } & Asymp sig. (2 \\
Pretest & Posttest & Pretest & Posttest & tailed) \\
\hline 15.25 & 18.25 & 1.28 & 1.13 & .002 \\
\hline
\end{tabular}

Selain itu, effect size bertujuan untuk melihat seberapa besar jarak antara dua skor yang ditunjukkan oleh mean skor tersebut. Berdasarkan Cohen's (d), nilai effect size berkisar antara 0 hingga 1 dimana nilai d .20, .50, dan .80 mewakili efek kecil, sedang, dan besar (Shaughnessy dkk., 2012). Hasil menunjukkan bahwa effect size skor asertivitas seksual bernilai .645 yang menjelaskan bahwa perbedaan jarak antara skor pretest dan postest tergolong sedang. Sedangkan statistical power (1- $\beta$ err prob) bernilai .654 dimana dapat dijelaskan bahwa variabel tersebut memiliki kekuatan sebesar $65.4 \%$ dalam menolak hipotesis nol (H0).

Berdasar tabel 8 dapat dijelaskan lebih spesifik mengenai dimensi refusal dimana skor posttest $(\mathrm{M}=18.25)$ lebih tinggi dibandingkan pretest $(\mathrm{M}=15.25)$. Selain itu, hasil uji hipotesis wilcoxon signed rank test menunjukkan bahwa Asymp sig. (2-tailed) yakni $.000(p<.05)$ dengan perbedaan mean -3.000. Hal ini menjelaskan bahwa terdapat perbedaan yang signifikan antara skor refusal sebelum dan setelah pelatihan diberikan, sehingga dapat disimpulkan adanya pelatihan dapat meningkatkan penolakan individu untuk melakukan seks tanpa persetujuan dari individu tersebut.

Uji hipotesis menunjukkan terdapat perbedaan antara pengetahuan partisipan sebelum mendapatkan pelatihan dan setelah mendapatkan pelatihan (Asymp sig 2 tailed $=.002$, diff. mean $=53.25)$. Hal ini berarti pelatihan seksualitas mampu meningkatkan pengetahuan partisipan mengenai seksualitas. Hal ini senada dengan penelitian Ningsih (2018) yang bertujuan untuk meningkatkan pengetahuan tentang seksualitas anak pada guru di Kabupaten Tanah Datar. Ningsih mengungkapkan bahwa pelatihan pendidikan seksualitas meningkatkan pengetahuan guru mengenai isu seksualitas. Hal ini disebabkan materi yang diberikan berkaitan dengan pentingnya pendidikan seksual, perkembangan seksual anak dan 
remaja, perilaku seksual remaja, serta pendidikan seksual untuk anak dan remaja.

Lebih jauh lagi, penelitian Kusumastuti (2010) terhadap siswi SMP menunjukkan bahwa terdapat hubungan antara pengetahuan yang didapatkan mengenai isu seksualitas dengan sikap seksual pranikah dimana individu yang memiliki lebih banyak pengetahuan cenderung untuk menghindari perilaku seks pranikah. Sejalan pula dengan penelitian Ningrum (2013) yang menjelaskan bahwa terdapat korelasi negatif yang signifikan antara pengetahuan seksualitas dan kesehatan reproduksi terhadap intensi perilaku seks pranikah. Remaja yang memiliki pengetahuan yang baik terkait isu seksualitas akan menurunkan intensi perilaku seks pranikah begitupun sebaliknya.

Berdasarkan asesmen menggunakan Sexual Assertiveness Scale (SAS), ada perbedaan skor pretest dan posttest pada partisipan penelitian ( sig 2 tailed $=.003$, diff. mean= 3.000). Lebih lanjut, terdapat pula perbedaan skor pretest dan posttest pada aspek refusal alat ukur SAS (sig 2 tailed $=.002$, diff. mean $=3.000)$. Hal ini menjelaskan bahwa pelatihan seksualitas meningkatkan asertivitas seksual partisipan, terutama pada aspek penolakan. Tholense dan Rahardjo (2013) mengungkapkan bahwa terdapat hubungan negatif antara asertivitas seksual dan perilaku seks pranikah pada remaja. Hal ini berarti bahwa semakin tinggi asertivitas seksual individu maka semakin rendah perilaku seks pranikah yang dilakukan.

Penelitian lainnya yakni Nasri dan Koentjoro (2015) juga mengungkapkan hal yang selaras dimana pelatihan asertivitas normatif juga efektif untuk menurunkan perilaku seksual pranikah. Individu yang memiliki tingkat asertivitas tinggi tidak akan mudah terpengaruh secara emosional dan mampu mempertahankan pendapat yang dianutnya. Pelatihan asertivitas juga dapat membantu individu untuk mengekspresikan diri, mempertahankan hak-hak pribadi, serta mencegah adanya perilaku seksual yang tidak diinginkan.

Kelebihan penelitian ini adalah masih belum meratanya pendidikan seksualitas disebabkan masyarakat masih menganggap bahwa isu seksualitas merupakan hal yang tabu. Lembar kerja dan slide presentation yang digunakan selama pelatihan juga sangat eye catching, berwarna, dan menarik minat partisipan pelatihan. Selain itu, partisipan juga tergolong aktif dalam bertanya dan atau menjawab pertanyaan. Hal ini sesuai dengan Kusumastuti (2010) yang mengungkapkan bahwa keaktifan partisipan untuk mengikuti setiap sesi psikoedukasi dan modul dengan tampilan yang menarik juga dapat menjadi salah satu faktor keberhasilan intervensi.

Selain itu, beberapa faktor yang juga mendukung keberhasilan intervensi ini adalah: (a) ruangan yang luas dan kondusif, (b) penerangan yang baik, (c) ruangan yang memiliki air conditioner (AC), (d) adanya Liquid Crystal Display (LCD) dan microphone, serta (e) dukungan dari pihak Puskesmas $\mathrm{X}$ sehingga acara dapat berjalan dengan maksimal. Hal ini juga sejalan dengan pendapat Nasri dan Koentjoro (2015) yang mengungkapkan bahwa keberhasilan pelatihan juga ditentukan oleh modul pelatihan, peserta pelatihan, trainer, serta fasilitas yang ada.

Keterbatasan penelitian ini adalah tidak adanya kelompok pembanding atau kelompok kontrol sehingga peneliti tidak mengetahui apakah peningkatan skor pengetahuan dan asertivitas seksual benarbenar disebabkan adanya intervensi atau disebabkan faktor lain di luar intervensi. Keterbatasan lainnya adalah adanya rentang usia partisipan yang berbeda, jumlah sampel yang kecil, dan semua peserta penelitian yang berjenis kelamin laki-laki. Selain itu, pertemuan pertama dan kedua pada pelatihan ini memiliki jarak selama satu minggu sehingga peneliti melakukan brainstorming dan review ulang pada pertemuan kedua sehingga partisipan masih 
Pelatihan "Sex? It Isn't Taboo Anymore" untuk Meningkatkan Pengetahuan dan Asertivitas Seksual Remaja (Ellyana Dwi Farisandy, Endang Retno Surjaningrum)

mengingat materi yang diberikan pada pertemuan pertama.

\section{Simpulan}

Pelatihan pengetahuan seksualitas bagi remaja efektif dalam meningkatkan pengetahuan partisipan berkaitan dengan isu seksualitas serta meningkatkan kemampuan partisipan dalam bertindak asertif secara seksual. Berdasarkan aspek refusal, terdapat peningkatan penolakan individu untuk melakukan seks yang tidak diinginkan antara sebelum dan setelah diadakannya pelatihan. Hal ini dapat disimpulkan bahwa pelatihan seksualitas efektif dalam meningkatkan pengetahuan partisipan terkait materi mengenai seksualitas serta meningkatkan asertivitas seksual partisipan, terutama untuk menolak secara asertif perilaku seks yang tidak diinginkan.

Saran yang dapat diterapkan kepada pihak Puskesmas adalah dengan membuat diskusi kelompok kecil setiap bulan mengenai edukasi seks yang difasilitasi oleh psikolog. Hal ini juga dapat digunakan sebagai sarana untuk memberikan pengetahuan mengenai seks edukasi terhadap anggota Posyandu remaja di Puskesmas X.

\section{Daftar Pustaka}

Abdissa, B., Addisie, M., \& Seifu, W. (2017). Premarital sexual practices, consequences and associated factors among regular undergraduate female students in Ambo University, Oromia Regional State, Central Ethiopia, 2015. Health Sci J. 11(1). https://doi.org/10.21767/1791809X.1000482

Abdullahi, M., \& Umar, A. (2013). Consequences of pre-marital sex among the youth a study of University of Maiduguri. IOSR Journal of Humanities and Social Science, 10(1), 10-17. https://doi.org/10.9790/083701011017
Akbar, Z., \& Muzdaliffah, F. (2014). Program pendidikan seks untuk meningkatkan proteksi diri dari eksploitasi seksual pada anak usia dini. Jurnal Parameter, 25, 115-122.

Amaliyah, S., \& Nuqul, F. L. (2017). Eksplorasi persepsi ibu tentang pendidikan seks untuk anak. Psymphatic,4(2), 157-166. https://doi.org/10.15575/psy.v4i2.1758

Asamoah, B. O., \& Agardh, A. (2018). Individual and family-level determinants of risky sexual behavior among swedish- and foreign-born young adults 18-30 years of age, residing in Skåne, Sweden. Arch Sex Behav, 4(2), 517-528. https://doi.org/10.1007/s10508-0170978-5

Berliana, S. M., Utami, E. D., Efendi, F., \& Kurniati, A. (2018). Premarital sex initiation and time interval to first marriage among Indonesians. Bulletin of Indonesian Economic Studies, 127. https://doi.org/10.1080/00074918.2 018.1440067

Elkington, K. S., Bauermeister, J. A., Robbins, R. N., Gromadzka, O., Abrams, E. J., Wiznia, A., Bamji, M., \& Mellins, C. A. (2012). Individual and contextual factors of sexual risk behavior in youth perinatally infected with HIV. AIDS Patient Care STDS, 26(7), 411-422. https://doi.org/10.1089/apc.2012.0005

Fajri, D. K. (2016). Gaya cinta dan perilaku seksual pranikah mahasiswa (Skripsi tidak diterbitkan). Universitas Muhammadiyah Malang.

German Foundation for World Population. (2006). Sexual and reproductiive health training manual for young people. German Foundation for World Population.

Ghaffari, M., Gharghani, Z. G., Mehrabi, Y., Ramezankhani, A., \& Movahed, M. (2016). Premarital Sexual IntercourseRelated Individual Factors Among Iranian Adolescents: A Qualitative 
Study. Iranian Red Crescent Medical Journal, 18(2), 1-7. https://doi.org/10.5812/ircmj.21220

Harsanti, I. P. (2012). Pengaruh latihan asertif terhadap perilaku seksual beresiko pada remaja di SMK Negeri " $X$ " Jember (Skripsi tidak diterbitkan). Universitas Jember.

Kartono, K. (2013). Patologi sosial. PT. Rajagrafindo Persada.

Kusumastuti, F. A. (2010). Hubungan antara pengetahuan dengan sikap seksual pranikah remaja. (Karya tulis ilmiah tidak diterbitkan). Universitas Sebelas Maret.

Kusumastuti, W. (2017). Pengaruh metode psikoedukasi terhadap perilaku seksual pranikah pada remaja putri. Jurnal Ilmiah Psikologi, 2(2), 155-166. https://doi.org/10.23917/indigenous.v2 i2. 4461

Lubis, D. V \& Oriza. D. (2000). Asertivitas seksual untuk perempuan Indonesia (suatu upaya pembuatan skala SASPI). Jurnal Psikologi Sosial, 1(8), 1-13.

Meilani, N., Shaluhiyah, Z., \& Suryoputro, A. (2014). Perilaku ibu dalam memberikan pendidikan seksualitas pada remaja awal. Jurnal Kesehatan Masyarakat Nasional, 8(8), 411-417.

Morokoff, P. J., Quina, K., Harlow, L. L., Whitmire, L., Grimley, D. M., Gibson, P. R., \& Burkholder, G. J. (1997). Sexual Assertiveness Scale (SAS) for women: Development and validation. Journal of Personality and Social Psychology, 73(4), 790804. https://doi.org/10.1037/00223514.73.4.790

Nasri, D., \& Koentjoro. (2015). Pelatihan asertivitas normatif terhadap perilaku seksual pranikah pada wanita bermasalah sebagai upaya preventif. Jurnal Ilmiah Psikologi Terapan, 3(2), 268-286.

Ningrum, N. A. (2013). Hubungan pengetahuan seksualitas dan kesehatan reproduksi; dan dukungan sosial dengan intensi perilaku seks pranikah pada remaja (Skripsi tidak diterbitkan). Universitas Airlangga.

Ningsih, Y. T. (2018). Pelatihan pendidikan seksual untuk meningkatkan pengetahuan tentang seksualitas anak pada guru di Kab. Tanah Datar. Jurnal RAP UNP, 9(2), 205-212.

Odek, T. (2006). Cultural challenges and sex education in Mageta Island, Kenya. Afrika Regional Sexuality Resource Center. 1-26.

Olubunmi, A. G. (2011). Impact of family type on involvement of adolescents in pre-marital sex. International Journal of Psychology and Counseling, 3(1), 15-19.

Rahardjo, W., Cutra, A. F., Saputra, M., Damariyanti, M., Ayuningsih, A. M., \& Siahay, M. M. (2017). Perilaku seks pranikah pada mahasiswa: Menilik peran harga diri, komitmen hubungan, dan sikap terhadap perilaku seks pranikah. Jurnal Psikologi, 44(2), 139-152.

https://doi.org/10.22146/jpsi.23659

Rahyani, K. Y., Utarini, A., Wilopo, S. A., \& Hakimi, M. (2012). Perilaku seks pranikah remaja. Jurnal Kesehatan Masyarakat Nasional, 7(4), 180-185.

Sarwono, S. W. (2003). Psikologi remaja. PT. Rajagrafindo Persada.

Scott, M. E., Wildsmith, E., Welti, K., Ryan, S., Schelar, E., \& StewardStreng, N. R. (2011). Risky adolescent sexual behaviors and reproductive health in young adulthood. Perspectives on Sexual and Reproductive Health, 43(2), 110118. https://doi.org/10.1363/431101

Shaughnessy, J. J., Zechmeister, E. B., \& Zechmeister, J. S. (2012). Research methods in psychology. McGraw Hill.

Sierra, J. C., Santos-Iglesias, P., \& VallejoMedina, P. (2012). Evaluación de la equivalencia factorial y métrica de la Sexual Assertiveness Scale (SAS) por sexo [Evaluation of the factorial and metric equivalence of the Sexual 
Pelatihan "Sex? It Isn't Taboo Anymore" untuk Meningkatkan Pengetahuan dan Asertivitas Seksual Remaja (Ellyana Dwi Farisandy, Endang Retno Surjaningrum)

Assertiveness Scale (SAS) by sex]. Psicothema, 24(2), 316-322.

Sunsern, R., \& Lawang, W. (2019). Bronfenbrenner's ecological model: Theoretical lens for a communitybased research. Journal of Health Science and Alternative Medicine, 1(1), 4-7. https://doi.org/10.14456/jhsam.2019.3

Tholense, N., \& Rahardjo, W. (2013). Asertivitas seksual dan perilaku seks pranikah pada mahasiswa. Jurnal Psikologi Ulayat, 1(2), 201-206. https://doi.org/10.24854/jpu22013-21

Utomo, I. D., \& Utomo, A. (2013). Adolescence pregnancy in Indonesia: A literature review. Australian Demographic and Social Research Institute: UNFPA (United Nations Population Fund).
Vallejo-Medina, P., \& Carlos-Sierra, J. (2015). Adaptation and validation of the sexual assertiveness scale (SAS) in a sample of male drug users. Spanish Journal of Psychology, 18 (21), 1-13. https://doi.org/10.1017/sjp.2015.25.

Warner, T. D. (2018). Adolescent sexual risk taking: the distribution of youth behaviors and perceived peer attitudes across neighborhood contexts. Journal of Adolescent Health, 62(2), 226233. https://doi.org/10.1016/j.jadohealt h.2017.09.007 
Psympathic, Jurnal Ilmiah Psikologi Desember 2019, Vol. 6, No. 2, Hal. : 229-240 